\section{Conflicts of interest: a review of institutional policy in Australian medical schools}

Eleanor Milligan Allan W Cripps

TO THE EDITOR: Comparing Australian medical school policies regarding conflict of interest (COI) to their United States counterparts, Mason and Tattersall $^{1}$ conclude that within Australia there is "a need for improved self-regulation”. The authors are applauded for highlighting this important aspect of medical education and organisational practice; however, the comparisons drawn fail to acknowledge a number of contextual differences that undermine the conclusions drawn.

First, significant cultural differences exist between Australia and the US with respect to historical market practices and commercial sponsorship within the tertiary education sector. ${ }^{2}$ The persistent failure of self-regulation in the US recently culminated in the passing of the Physicians Payment Sunshine Provision, which now mandates transparent disclosure of all ( $>$ \$10) payments, gifts and sponsorships, and imposes significant penalties for failure to report. ${ }^{3}$ Arguably, this changing legislative landscape has encouraged US medical schools to develop more robust COI policies rather than a proactive commitment to manage COI.

Second, unlike in the US, most of Australia's 20 medical schools sit within publicly funded universities, where central policy regulation of COI prevails. Mason and Tattersall's ${ }^{1}$ suggestion that each school have its own COI policy without reference to the overarching university's COI policy is flawed, particularly in a wider academic environment where industry sponsorship of education and commercialisation in research are increasingly encouraged as a desirable strategy to supplement falling levels of Commonwealth resourcing.

Third, despite the lack of policies in Australian medical schools, positive performances with respect to COI in the curriculum were noted, ${ }^{1}$ demonstrating that lack of policy does not necessarily hinder appropriate curriculum content.

Finally, on becoming doctors, medical students are bound by their professional codes of practice, codes of ethics, organisational policies and state and federal legislation, which outline the obligation to act within the recognised standards of the profession. ${ }^{4}$ While medical schools have a significant role to play in preparing future doctors to effectively recognise bias and appropriately manage COI, ${ }^{5}$ their ability to enforce more rigorous standards than those which apply within the professional community at large is doubtful. The adequacy of current professional codes is a matter for further debate.

Medical schools exist within the wider context of the university, the community and the overarching political and legal landscape that governs their resourcing and practices. These factors must be taken into account when judging the actions of medical schools. To present Australian medical schools as lacking ${ }^{1}$ on the basis of a decontextualised comparison with US schools may be overly simplistic.

Eleanor Milligan Academic Lead — Law, Ethics and Professional Practice, School of Medicine Allan W Cripps Pro Vice-Chancellor (Health) Griffith University, Southport, QLD. e.milligan@griffith.edu.au

1 Mason PR, Tattersall MHN. Conflicts of interest: a review of institutional policy in Australian medical schools. Med J Aust 2011; 194: $121-125$. http://www.mja.com.au/public/issues/194_03_0 70211/mas10914 fm.html

2 Association of American Medical Colleges. Industry funding of medical education. Report of an AAMC task force. Washington, DC: AAMC, 2008. http://www.ucsfcme.com/news/IndustryFunding MedicalEduation.pdf (accessed Jun 2011).

3 Policy and Medicine. Physician Payment Sunshine Provisions: Patient Protection Affordable Care Act passed the House. 2010 Mar http://www.policymed.com/2010/03/physicianpayment-sunshine-provisions-patientprotection-affordable-care-act.html (accessed Jun 2011).

4 Australian Medical Association. Position statement on doctors' relationships with industry - 2010. Canberra: AMA, 2010. http://ama.com.au/node/5421 (accessed Jun 2011).

5 Carmody DM, Mansfield PR. What do medical students think about pharmaceutical promotion? Aust Med Student J 2010; 1: 54-57. 